\title{
Quantitative aspects of directly coupled supercritical fluid extraction-capillary gas chromatography with a conventional split/splitless injector as interface
}

Citation for published version (APA):

Lou, X. W., Janssen, J. G. M., \& Cramers, C. A. (1993). Quantitative aspects of directly coupled supercritical fluid extraction-capillary gas chromatography with a conventional split/splitless injector as interface. Journal of High Resolution Chromatography, 16(7), 425-428. https://doi.org/10.1002/jhrc.1240160709

DOI:

10.1002/jhrc.1240160709

Document status and date:

Published: 01/01/1993

Document Version:

Publisher's PDF, also known as Version of Record (includes final page, issue and volume numbers)

Please check the document version of this publication:

- A submitted manuscript is the version of the article upon submission and before peer-review. There can be important differences between the submitted version and the official published version of record. People interested in the research are advised to contact the author for the final version of the publication, or visit the DOI to the publisher's website.

- The final author version and the galley proof are versions of the publication after peer review.

- The final published version features the final layout of the paper including the volume, issue and page numbers.

Link to publication

\footnotetext{
General rights

- You may freely distribute the URL identifying the publication in the public portal. follow below link for the End User Agreement:

www.tue.nl/taverne

\section{Take down policy}

If you believe that this document breaches copyright please contact us at:

openaccess@tue.nl

providing details and we will investigate your claim.
}

Copyright and moral rights for the publications made accessible in the public portal are retained by the authors and/or other copyright owners and it is a condition of accessing publications that users recognise and abide by the legal requirements associated with these rights.

- Users may download and print one copy of any publication from the public portal for the purpose of private study or research.

- You may not further distribute the material or use it for any profit-making activity or commercial gain

If the publication is distributed under the terms of Article 25fa of the Dutch Copyright Act, indicated by the "Taverne" license above, please 


\title{
Quantitative Aspects of Directly Coupled Supercritical Fluid Extraction-Capillary Gas Chromatography with a Conventional Split/Splitless Injector as Interface
}

\author{
Xianwen Lou, Hans-Gerd Janssen*, and Carel A. Cramers
}

Eindhoven University of Technology, Laboratory of Instrumental Analysis, P. O. Box 513, 5600 MB, Eindhoven, The Netherlands

\section{Key Words:}

On-line SFE-GC

Split/splitless interface

Quantitative aspects

Discrimination

Reproducibility

\section{Summary}

The quantitative aspects of on-line supercritical fluid extractioncapillary gas chromatography (SFE-GC) with a split/splitless injector as interface were investigated. Special attention was paid to the discrimination behavior and the reproducibility of the split/splitless interface. A simple experimental set-up is proposed that allows accurate quantitation in on-line SFE-split GC. The results obtained in on-line SFE-GC compare favorably with those from conventional $\mathrm{GC}$ with split injection. Discrimination was found to be absent when working at sufficiently high interface temperatures. Finally, the effects of the carbon dioxide flow rate, interface temperature and split ratio on both discrimination and reproducibility were studied.

\section{Introduction}

Supercntical fluid extraction (SFE) is a rapidly growing technique for sample preparation [1]. SFE has a number of important advantages over conventional liquid extractions. Among these, the ease with which on-line combination of SFE sample preparation with chromatographic analysis can be obtained is one of the most important. Various interfaces for on-line SFE-GC have been described in literature [2-4]. Of these interfaces the split injector is the easiest: to use and the most rugged device.

In SFE-GC with a split injector as the interface, the SFE restrictor is inserted directly through the septum into a conventional split/splitless injection port. The injector is heated to prevent plugging of the restrictor. The GC column is cooled to refocus the extracted components [5]. Split SFE-GC has been shown to work well for samples that have high concentrations of extractable components, for wet samples, and for extractions using modifiers [6-8].

In a hyphenated method, the interface is the key to the technique. In conventional GC with split injection, the flow split ratio is often not a correct representation of the true sample split ratio. Moreover, discrimination can occur as a consequence of large differences in volatility. In SFE-GC with a split/splitless injector as the interface, all the solutes are initially dissolved in the supercritical fluid. On transfering the sample to the GC, the supercritical fluid is expanded which results in a large volume of gaseous sample. In this regard, on-line SFE-split GC is clearly different from a conventional split injection in capillary GC

Little attention has been paid in the literature to quantitative aspects of the split injector when used as the interface in on-line SFE-GC. The discrimination behavior and reproducibility of the split injector in on-line SFE-GC have not yet been investigated. Calibration of on-line SFE-split GC is frequently camied out by introducing a calibration standard directly into the split injector using a syringe

[9]. In that case, however, the volume of sample that is introduced into the injector is not known accurately and there could be discrimination against volatility. Hence, accurate calibration cannot be obtained. To circumvent these problems, we recently proposed incorporation of an injection valve in the SFE-GC set-up. With this valve accurately known volumes of a calibration standard can be introduced without discrimination [10].

In this paper, the ability to analyze components of different volatilities by on-line SFE-split GC is evaluated by model experiments. Furthermore, the reproducibility of SFE-GC using the split injector as the interface is evaluated. Also the influence of the carbon dioxide flow rate and the carrier gas flow on the performance of the system is investigated.

\section{Experimental}

Figure 1 shows a schematic diagram of the system used in the experiments. No extraction cell was included in the system. On-line SFE-GC experiments were modeled by injecting a standard solution of $n$-alkanes in hexane directly into the carbon dioxide flow stream at ambient temperature using an LC injection valve (CH 6214, VICI AG, Schenkon, Switzerland). In this way, solutions with known concentrations of the test components could be introduced directly into the split/splitless interface. By using this approach, the discrimination behavior and reproducibility of the interface could be studied accurately as all errors introduced by the SFE part of the experimental set-up were excluded.

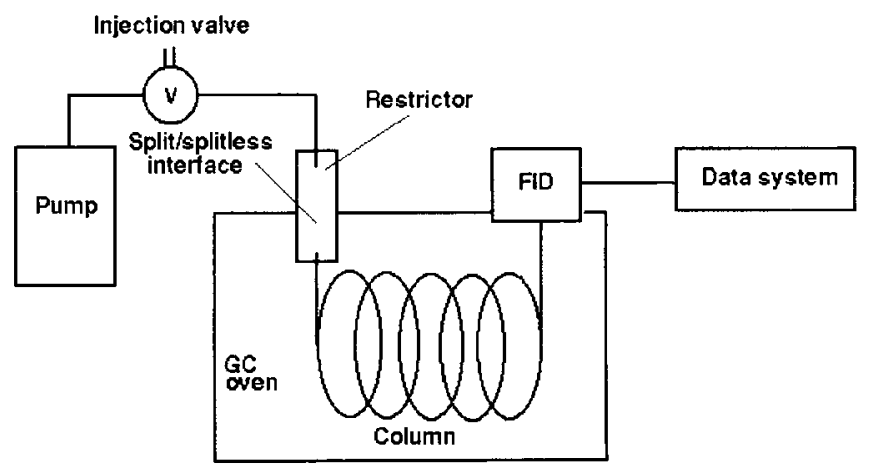

Figure 1

Schematic diagram of on-line SFE-GC model system used for evaluation of the split interface. 
All GC analyses were carned out on a HRGC 5300 (Mega series, Carlo Erba Strumentazione, Milano, Italy) equipped with a flame ionization detector. Helium was used as the carrier gas. A crosslinked methyl-silicone fused-silica capillary column $(25 \mathrm{~m} \times 0.32 \mathrm{~mm}$ i.d., film thickness $0.52 \mu \mathrm{m})$ from Hewlett-Packard (Avondale, USA) was used for all GC analyses. The carbon dioxide used in the experiments had a purity of $99.996 \%$ (Intermar B. V., Breda, The Netherlands). A modified Varian 8500 syringe pump (Varian Associates, Sunnyvale, California, USA) was used to deliver the carbon dioxide. The carbon dioxide pressure was maintained at $300 \mathrm{~atm}$. A stainless steel capillary $(210 \mu \mathrm{m}$ i.d.) was used as the restrictor. The end of the restrictor was crimped to give the desired flow rate. The carbon dioxide gas flow rate was measured with a flow meter after the restrictor was inserted through the septum into the heated liner of the split injector. A liner with a glass frit was used. For the SFE-GC analyses, the column temperature was initially set at $30^{\circ} \mathrm{C}$ to trap the components on the head of the GC column. After 15 minutes, which was found to be sufficient for transferring the components to the GC column, the oven temperature was programmed to $325^{\circ} \mathrm{C}$ at $10 \% \mathrm{~min}$. The SFE restrictor was left in the injector during the entire period of experimental work. Except in the experiments to study the effect of the split ratio, the split flow was kept at $240 \mathrm{~mL} / \mathrm{min}$ (helium and carbon dioxide).

\section{Results and Discussion}

The split/splitless injector has been widely used as a sample introduction system for capillary GC. It has also been found to be a simple and useful interface for SFE-GC. In order to compare the SFE-GC interface with a conventional split/splitless injector with regard to discrimination and reproducibility of peak areas a solution of $n$-alkanes ranging from $\mathrm{C}_{8}$ to $\mathrm{C}_{36}$, at concentrations of approximately $0.80 \mathrm{mg} / \mathrm{ml}$ in hexane was injected directly with a syringe and through the SFE restrictor, respectively. The components were selected to cover a wide span of volatilities. The boiling points range from $126^{\circ} \mathrm{C}\left(\mathrm{C}_{8}\right.$, atmospheric pressure) to $265^{\circ} \mathrm{C}\left(\mathrm{C}_{36}, 1\right.$ torr). All the solutes except $\mathrm{C}_{8}$ and $\mathrm{C}_{10}$ were effectively trapped on the head of the GC column and showed up as sharp, symmetrical peaks. In the discrimination studies, $\mathrm{C}_{22}(0.80 \mathrm{mg} / \mathrm{ml}$ in hexane) was selected as the internal standard. The concentrations of the other components were calculated from the ratios of their peak areas relative to $\mathrm{C}_{22}$. The results are shown in Table 1 and Figure 2.

Table 1

Comparison of concentration values obtained with simulated online split SFE-GC and conventional split injection in GC.

\begin{tabular}{|c|c|c|c|c|c|}
\hline & \multirow[b]{2}{*}{$c^{a, b)}$} & \multicolumn{2}{|c|}{ SFE-GC } & \multicolumn{2}{|c|}{ split injection GC } \\
\hline & & $c^{\text {a) }}$ & RSD\% ${ }^{\mathrm{cl}}$ & $c^{\text {a) }}$ & $\mathrm{RSD} \%{ }^{\mathrm{cl}}$ \\
\hline$\overline{\mathrm{C}_{12}}$ & 0.90 & 0.90 & 1.4 & 1.19 & 6.5 \\
\hline $\mathrm{C}_{14}$ & 0.92 & 0.91 & 1.3 & 1.16 & 5.4 \\
\hline $\mathrm{C}_{16}$ & 0.91 & 0.91 & 0.6 & 1.16 & 5.6 \\
\hline $\mathrm{C}_{18}$ & 0.92 & 0.93 & 1.7 & 1.08 & 2.3 \\
\hline $\mathrm{C}_{20}$ & 0.76 & 0.76 & 0.8 & 0.81 & 2.6 \\
\hline $\mathrm{C}_{22}$ & 0.80 & & al standa & & \\
\hline $\mathrm{C}_{24}$ & 0.85 & 0.85 & 0.5 & 0.80 & 4.2 \\
\hline $\mathrm{C}_{28}$ & 0.77 & 0.77 & 0.8 & 0.65 & 9.7 \\
\hline $\mathrm{C}_{32}$ & 0.81 & 0.80 & 1.6 & 0.62 & 13.1 \\
\hline $\mathrm{C}_{36}$ & 0.81 & 0.78 & 1.3 & 0.58 & 15.1 \\
\hline
\end{tabular}

a) Concentration ( $\mathrm{mg} / \mathrm{ml}$ in hexane). ${ }^{\text {b) }}$ Values obtained by on-column injection.

c) Rel. std. deviation of the conc. values $(n=5)$. d) $\mathrm{CO}_{2}$ gas flow $=93 \mathrm{ml} / \mathrm{min}$.
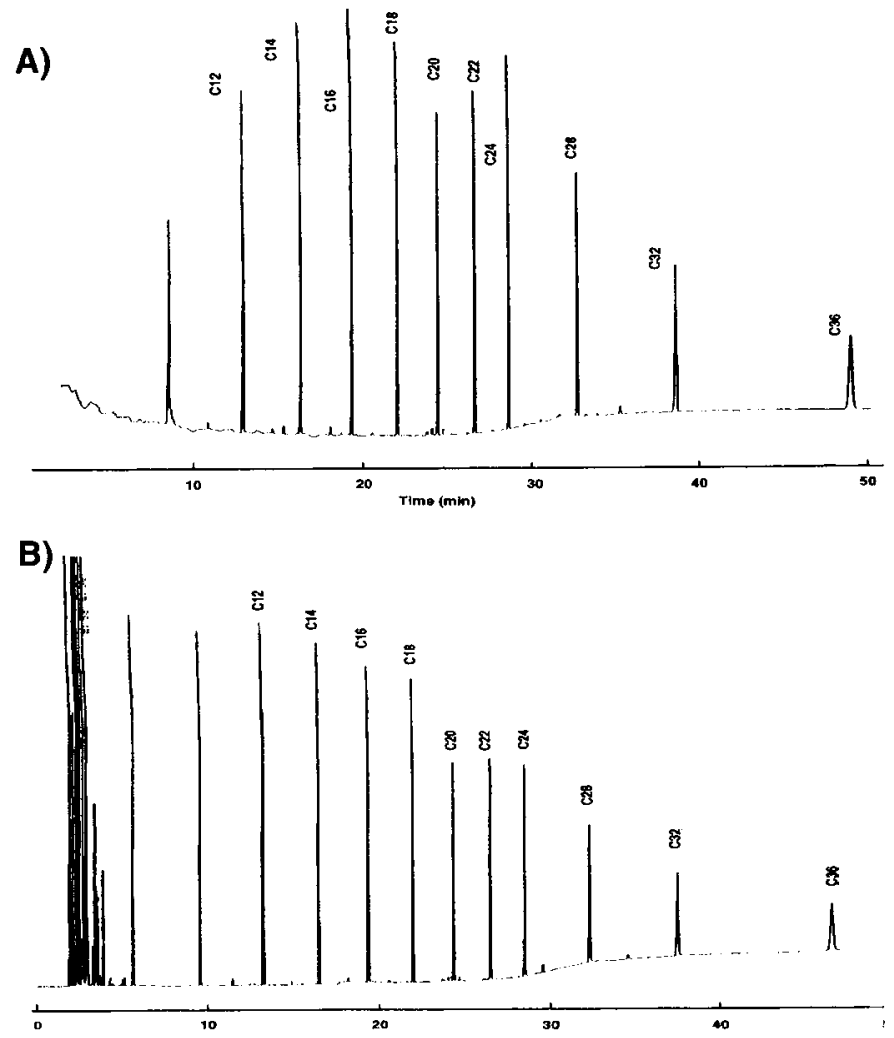

Figure 2

Comparison of chromatograms of $n$-alkanes with SFE-split GC and conventional split injection in GC. A) SFE-GC; B) conventional split injection in GC.

Figure 2 compares the chromatogram of a simulated on-line SFEsplit GC experiment (Figure 2A) with that of a conventional split injection in $\mathrm{GC}$ (Figure $2 \mathrm{~B}$ ). A summary of the quantitative data is given in Table 1. As can be seen from this table, significant discrimination occurs in the conventional split injection. When the same sample is introduced through the SFE restrictor, discrimination is absent, as is evidenced by the data given in Table 1. From this, it can be concluded that calibration of an on-line SFE-GC system by injecting a standard solution directly into the split injector using a syringe will give incorrect quantitative data for components that are liable to discrimination. In the experiment described above, the temperature of the split injector was $320^{\circ} \mathrm{C}$. When similar experiments were performed at a split injector temperature of $200^{\circ} \mathrm{C}$, serious discrimination is also observed in on-line SFE-GC (Table 2). This is most likely due to droplet- or aerosol formation of the extracted components when too low temperatures are used. Hence, it is clear that in order to obtain discrimination-free operation in on-line SFE-GC using the split injector as the interface, the interface temperature should be chosen sufficiently high. If this demand is met, quantitative analyses of samples covering a wide range of volatilities requires only one internal standard since discrimination against volatility is absent.

To study the effect of the carbon dioxide flow rate on the amount of solute transferred into the GC column, a number of experiments at different carbon dioxide flow rates was performed. In these experiments the total split flow rate (carbon dioxide + helium) was kept constant by adjusting the helium flow. A total split flow of 240 $\mathrm{ml} / \mathrm{min}$ was used. Also the linear velocity of the carrier gas was kept constant. This was achieved by adjusting the inlet pressure of the column. As both the split flow and the column flow are constant, the split ratio remains the same in each of the experiments. The results of the experiments are shown in Figure 3. From this figure 
Table 2

Effect of interface temperature on quantitative results and reproducibility ${ }^{a)}$.

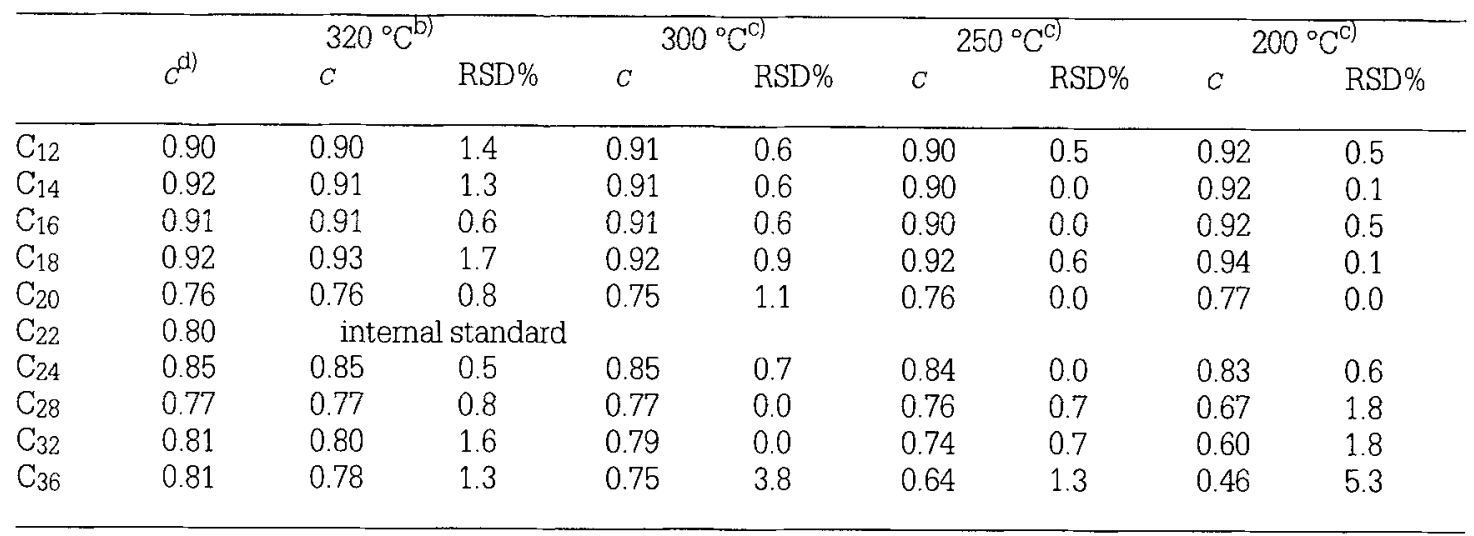

a) Carbon dioxide gas flow rate $=93 \mathrm{mi} / \mathrm{min}$.

b) Based on 5 injections.

c) Based on 3 injections

d) Concentrations obtained by on-column injection.

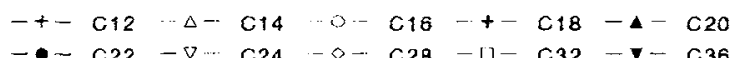

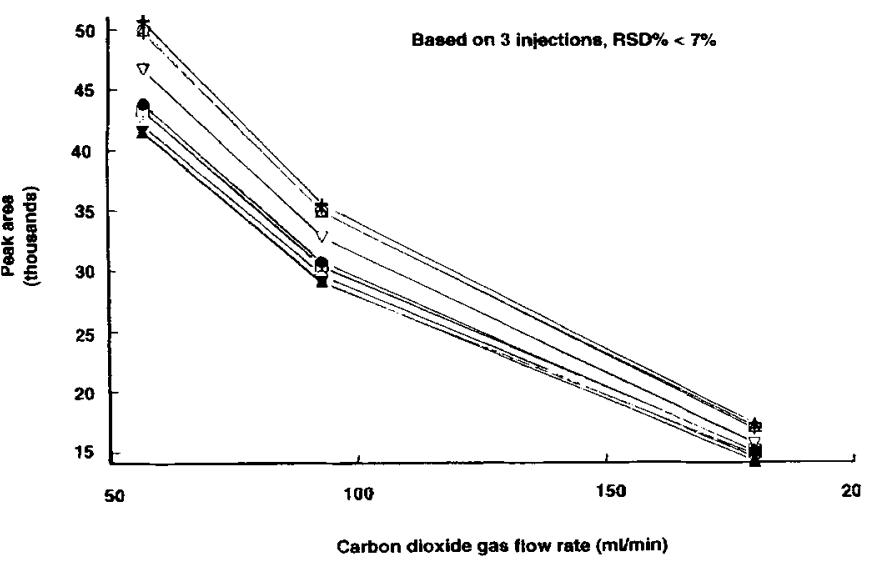

Figure 3

Effect of carbon dioxide flow rate on peak areas.

it can be seen that the peak areas decrease with increasing carbon dioxide flow. This is surprising because the split ratio remains constant. Hence, one would expect the peak areas to be independent of the carbon dioxide flow.

From the results presented in Figure 3, it appears that the behavior of a split injector in on-line SFE-GC is markedly different from that normally observed in conventional GC. To study the effect of the split flow on peak areas in more detail, a second series of experiments was performed. In these experiments, the split flow was changed from $450 \mathrm{ml} / \mathrm{min}$ to $75 \mathrm{ml} / \mathrm{min}$ at a constant carbon dioxide flow and column flow rate. Only the flow rates of helium were different in the two experiments. Hence, the split ratios are different in these two cases. The results are summarized in Table 3. As can be seen from this table, almost no changes in absolute peak areas occur despite the large difference in the split ratios. Also this observation is in contrast to expectation. If, on the other hand, the column flow rate was increased, the peak areas increased as is expected (see Table 3).

Most likely, the effects described above are caused by the flow pattern in the split injector. In Figure 4, a flow pattem is proposed
Table 3

Effect of split flow and carrier gas velocity on peak area ${ }^{a)}$.

\begin{tabular}{|c|c|c|c|c|c|c|}
\hline & \multicolumn{2}{|c|}{$\begin{array}{l}u_{0}=26.5 \mathrm{~cm} / \mathrm{s}^{\mathrm{b})} \\
F_{\text {split }}=450 \mathrm{ml} / \mathrm{min}^{\mathrm{c})}\end{array}$} & \multicolumn{2}{|c|}{$\begin{array}{l}u_{0}=26.1 \mathrm{~cm} / \mathrm{s}^{\mathrm{b})} \\
F_{\text {split }}=75 \mathrm{ml} / \mathrm{min}^{\mathrm{c})}\end{array}$} & \multicolumn{2}{|c|}{$\begin{array}{l}u_{0}=64.5 \mathrm{~cm} / \mathrm{s}^{\mathrm{b})} \\
F_{\mathrm{split}}=75 \mathrm{ml} / \mathrm{min}^{\mathrm{c}}\end{array}$} \\
\hline & area & $\mathrm{RSD} \%$ & area & $\mathrm{RSD} \%$ & area & $\mathrm{RSD} \%$ \\
\hline $\mathrm{C}_{12}$ & 36974 & 4.6 & 35865 & 2.1 & 93143 & 5.2 \\
\hline $\mathrm{C}_{14}$ & 36964 & 4.5 & 36022 & 1.8 & 92915 & 6.2 \\
\hline $\mathrm{C}_{16}$ & 36887 & 4.7 & 36105 & 1.8 & 93860 & 6.2 \\
\hline $\mathrm{C}_{18}$ & 37406 & 4.7 & 36778 & 1.8 & 94952 & 6.2 \\
\hline $\mathrm{C}_{20}$ & 30685 & 4.7 & 30185 & 1.5 & 78048 & 6.2 \\
\hline $\mathrm{C}_{22}$ & 32465 & 4.8 & 31802 & 1.8 & 82998 & 6.8 \\
\hline $\mathrm{C}_{24}$ & 34542 & 4.7 & 33889 & 1.7 & 88219 & 6.5 \\
\hline $\mathrm{C}_{28}$ & 31499 & 4.7 & 30639 & 2.7 & 80412 & 6.5 \\
\hline $\mathrm{C}_{32}$ & 32257 & 4.6 & 31578 & 3.2 & 83091 & 6.3 \\
\hline $\mathrm{C}_{36}$ & 31089 & 5.0 & 29979 & 3.9 & 79395 & 6.2 \\
\hline
\end{tabular}

a) Carbon dioxide gas flow: $78 \mathrm{ml} / \mathrm{min}$, interface temperature: $320^{\circ} \mathrm{C}$, based on 3 injections.

b) Carrier gas velocity.

${ }^{c)}$ Split flow rate.

Figure 4

Schematic representation of the solute transfer process in the liner.

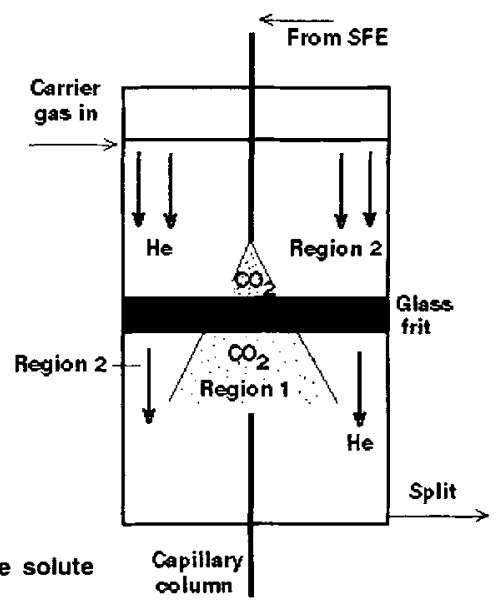


that could account for those observations. In the center of the liner, the linear velocity of the carbon dioxide expanding from the SFE restrictor is extremely high. Due to this high velocity the carbon dioxide flow is not homogeneously mixed with the helium. Hence, the gas in the central region of the liner almost exclusively consists of carbon dioxide. Thus, in our experiments, the carrier gas is mainly carbon dioxide, regardless of the magnitude of the helium flow through the iner. At increased carbon dioxide flow rates, the central region tends to expand, and the fraction of the solutes transferred to the capillary column is reduced, again regardless of the magnitude of the helium flow rate. This explains the decrease of the peak areas at increased carbon dioxide flow rates as observed in Figure 3. From the flow pattern in the liner it is also easily understood why the amount of solute entering the column is almost independent of the split flow (see Table 3). If the split flow rate is increased while keeping the velocity of the carrier gas and the carbon dioxide flow constant, only the flow rate in region 2 increases and there is almost no change in the central region (region 1).

No significant influence of the carbon dioxide flow rate, split flow and carrier gas velocity on the reproducibilities of absolute peak areas and on the discrimination behavior was found in our experiments.

The complex flow pattern in the liner complicates quantitation in on-line SFE-split GC, because the actual sample split ratio is not known. Hence, accurate calibration can only be obtained by introducing the calibration standard in the same way as the real sample is introduced, i.e. through the SFE restrictor. Also method development in on-line SFE-GC is seriously complicated by the fact that the sample split ratio is a function of the carbon dioxide flow. For example, when the extraction pressure is varied in order to establish the influence of this parameter on the extraction yield, the carbon dioxide flow and, hence, the fraction of the extracted components that is transferred into the column, changes.

\section{References}

(1) T.L. Chester, J.D. Pinkston, and D.E. Raynie, Anal Chem. 64 (1992) 153R.

[2] S.B. Hawthorne, D.J. Miller, and M.S. Krieger, J. Chromatogr. Sci. 27 (1989) 347

[3] J.M. Levy, J.P. Guzowski, and W.E. Huhak, HRC\&CC 10 (1987) 337.

[4] R.J. Houben, H.-G.M. Janssen, P.A. Leclercq, J.A. Rijks, and C.A. Cramers, HRC\&CC 13 (1990) 669.

[5] J.M. Levy and A.C. Rosselli, Chromatographia 28 (1989) 613.

[6] M.L. Lee and K.E. Markides (eds.), Analytical Supercritical Fluid Chromatography and Extraction, Chromatography Conferences, Provo, UT, (1990), p. 339.

[7] S.B. Hawthorne, D.J. Miller, and J.J. Langenfeld, J. Chromatogr. Sci. 28 (1990) 2.

[8] J.M. Levy, R.A. Cavalier, T.N. Bosch, A.F. Rynaski, and W.E. Huhak, J. Chromatogr. Sci. 27 (1989) 341.

(9) J. M. Levy, A. C. Rosselli, D. S. Boyer, and K. Cross, HRC\&CC 13 (1990) 418.

[10] H.-G. Janssen, C.A. Cramers, L.M. van der Meulen-Kuijk, and A.L.C. Smit, in: P. Sandra (Ed.), Proceedings og the 15 th International Symposium on Capillary Chromatography, Huethig Verlag, Heidelberg, 1993, p. 1705.

Received: May 6, 1993 Accepted: June 14, 1993 